\title{
Commentary
}

\section{Strikes and Doctors- psychosocial and ethical dilemmas}

\author{
Avinash De Sousa ${ }^{1}$ Shivanshu Shrivastava ${ }^{2}$ Sushma Sonavane ${ }^{3}$ \\ Nilesh Shah ${ }^{4}$
}

1. Research Associate, 2. Research Assistant, 3. Professor and 4. Professor and Head, Department of Psychiatry, Lokmanya Tilak Municipal Medical College, Mumbai. Email: avinashdes888@gmail.com

\begin{abstract}
This paper is a commentary on whether doctors have the right to strike work or not while keeping in mind, psychosocial and ethical implications of the same. Certain guidelines and criteria that may be applicable when examining doctors on strike are elucidated and discussed.
\end{abstract}

Key words: doctors, strike, ethical, psychosocial.

Introduction: Strikes involving medical doctors have been around since time immemorial. Strikes in India and Asia differ from the west often in the factors that lead to the strike. The following paper is a commentary on whether strikes by doctors are needed, if yes then are they ethical? and finally are there some criteria or guidelines that can be laid down regarding doctors that strike work? These views are generalized to doctors across various nations, though in individual cases, the nature and reasons as well as the need to strike work may differ.

\section{Critical Points When Examining Strikes Involving Doctors:}

- $\quad$ Strikes among doctors differ immensely when the strike involves senior versus junior doctors. The senior doctors would often go on strike when new laws that restrict their freedom and work come into place, in some cases a need for increased salaries and at times protesting against violence towards a senior colleague. Junior doctors often go on strike when they demand increase in stipends or violence by patients relatives towards them or if there is some government bond fulfillment or course fee issues that worry them ${ }^{1}$.

- Doctors are often regarded as selfless people working in the honourable profession. With the advent of private hospitals and public private collaborations, doctors are often made to sign work contracts and forced into bonded labour. Does this mean that we equate doctors with industrial labourers and other workforce or should we have separate category that we assign to them. It is a debate that will need considerable thought and deliberation ${ }^{2}$.

- Doctors often are asked to adhere to a professional code of conduct as per the ethical guidelines of various medical associations and councils. Worldwide doctors adhere to the same. The same ethical guidelines do not specify what the doctor must do when similar moralities are not 
adhered to patient's relatives and kin when talking, dealing and interacting with doctors. Many times, doctors are manhandled, faces blackened and beaten up by relatives. Angry mobs destroy their clinics and nursing homes causing damage to property and life beyond reasonable doubt ${ }^{3}$.

- Another thought provoking area is the question whether there could be criteria that may be fulfilled regarding doctors going on strike and whether a strike by doctors is justified after those criteria are fulfilled. Interestingly it is very difficult to draft out such criteria in black and white and it is further interesting to note whether fulfillment of such criteria would make doctors striking as legal and legitimate ${ }^{4}$.

\section{When Can a Doctor Go on Strike}

The following sections draws on literature related to doctor's strikes and takes a peek into whether criteria can be drawn with regarding to calling a strike by doctors just and needed.

- People believe that when the cause is just and backed by the right intentions, any form of agitation is reasonable. The same way a doctor's strike when just and with the right intention of greater good of most doctors is considered fine. The strike must not be political or aimed at political ambitions, it should not be because of one man's ire against the government or an act meant for the aggrandizement of one's ego or a means to show one's power ${ }^{4}$.

- Wage or salary disputes come under just causes as doctor's that cannot provide for one's self and their family may often demonstrate a decline in medical skills and this may affect the public health of a nation in general. The wages of a doctor who puts in hours of work often neglecting personal and family time must at least compensate partially for these sacrifices. The issue of wages is of public health importance as the poor wages of doctors force them to work excessively long hours, compromising the quality of the medical care they offer and their ability to act in the best interest of their patients ${ }^{5}$. Poor wages and salaries will also affect the medical teaching in a country as young people may not take up medicine fearing poor salaries and seeks other sources of vocation and employment while senior medical teachers may go abroad or to arenas where the salary justifies their talent and expertise ${ }^{6}$.

- The criterion of just cause often demands a utilitarian philosophy determinant which demonstrates that ultimately, the beneficial repercussions of the strike on the health system that must outweigh the temporary disruption and suffering caused by it. During the strike it is pivotal that doctors must demonstrate the right intention and they should remain benevolent to their cause while avoiding gall spewing acts that may compromise their just cause ${ }^{7}$.

- While striking it is of paramount importance that medical emergency services remain unaffected thereby adhering to medical oath and ethical guidelines while yet continuing the fight for one's rights. Just like in a war between two nations, in a doctor's strike unnecessary civilian 
casualties must be avoided and doctors on strike should continue to provide at least such critical services as emergency care and intensive care ${ }^{8}$.

- It is very essential that doctor's that strike be assured of success in some way as very often many strikes in the long run prove futile and catastrophic. For example the strike by junior doctors citing an increase in stipends led to the government increasing the stipend by $20 \%$ while medical course fees were hiked within a month of this ruling by $60 \%$. Thus the loss financially was for the doctors who ended up paying more than they did prior to the strike.

- Strike must often be the last resort measure and not the first. Doctors being a part of essential services must not strike unless all other means and negotiations and talking cures fail. A formal announcement of the strike, adequate warning, candle marches, silent protests and press briefings followed by a one day token strike must lead up to the final strike. This provides a mechanism to help patients prepare in advance for the unsettling effects of the strike i.e. by relocating, stocking medication, and booking appointments with alternative providers ${ }^{8}$.

Conclusions: The authors of this paper wish to state that they believe that strikes are unnecessary and uncalled for especially when in a profession like medicine. The aim of this paper is to provide an unbiased view regarding some considerations to be made when doctors have no resort but go on strike. As doctors, our duties towards our patients is one of the highest importance, but people must not forget that doctors are human beings, they have a life, a family, responsibilities and bills to pay like all of us. We must remember that human dignity and respect must be preserved from doctor towards a patient and the converse also holds true. Doctors are usually very patient and bear a lot silently with courage, but the old adage comes into play once in a while when things cannot be taken lying down....'When the going gets tough, then the tough get going'!

\section{References:}

1. Ekbal B. IMA strike: need for public debate. Indian J Med Ethics 2012; 9 (4):226-8.

2. Frizelle F. Is it ethical for doctors to strike? N Z Med J 2006;119(1236): 2037

3. Sachdev PS. Doctors' strike-an ethical justification. N Z Med J 1986; 99(803): 412-14.

4. Ogunbanjo GA, van Bogaert DK. Doctors and strike action: Can this be morally justifiable? SA Fam Pract 2009; 51(4): 306-8.

5. Grosskopf I, Buckman G, Garty M. Ethical dilemmas of the doctors' strike in Israel. J Med Ethics 1985; 11: 70-71.

6. Selemego M. Criteria for just strike action by medical doctors. Indian J Med Ethics 2014; 11(1): 35-8.

7. Dunn HP. Resident hospital doctors' strike. N Z Med J 1992; 105: 20-1.

8. Chima SC. Global medicine: Is it ethical or morally justifiable for doctors and other healthcare workers to go on strike? BMC Medical Ethics 2013; 14(Suppl 1): S5-15.

Conflict of Interest: Author declared no conflict of interest and no financial disclosures. 